\title{
МОТИВИ ВТРАТИ ВІНКА В УКРАЇНСЬКИХ НАРОДНИХ ПІСНЯХ ПРО КОХАННЯ
}

\author{
Бокало Ірина \\ викладач філологічних дисциплін Відокремленого підрозділу \\ Національного університету біоресурсів і природокористування Украӥни \\ «Ірпінський економічний коледж», Украӥна, Ірпінь
}

DOI: https://doi.org/ 10.31435/rsglobal_ws/28022019/6361

\section{ARTICLE INFO}

Received: 18 December 2018

Accepted: 20 February 2019

Published: 28 February 2019

\section{KEYWORDS}

Ukrainian folk love songs, ethno-ethics,

deceived girl,

wreath,

euphemisms.

\begin{abstract}
Ukrainian folk love songs as one of the most relevant genres have retained a lot of information about the norms of ethics and morals of the Ukrainian youth at the end of the XIX - early XX century. Particularly interesting are texts which contain information about the loss of maiden innocence, are reflected in the motifs of wreath loss. In folk love songs with the motifs of wreath loss, often are being used images-symbols of a wreath, braids, weed field, destiny. National aesthetics rarely judge girl who committed such a moral crime, but mostly sympathizes with her, uses the examples of such situations to warn young people from committing such offenses.
\end{abstract}

Citation: Бокало Iрина. (2019) Motyvy Vtraty Vinka v Ukrainskykh Narodnykh Pisniakh pro Kokhannia. World Science. 2(42), Vol.2. doi: 10.31435/rsglobal_ws/28022019/6361

Copyright: () 2019 Бокало Ірина. This is an open-access article distributed under the terms of the Creative Commons Attribution License (CC BY). The use, distribution or reproduction in other forums is permitted, provided the original author(s) or licensor are credited and that the original publication in this journal is cited, in accordance with accepted academic practice. No use, distribution or reproduction is permitted which does not comply with these terms.

Вступ. Усна словесність «закарбувала» у собі норми моралі та поведінки, яких потрібно було дотримуватися в родинному та суспільному побуті. Джерелом вивчення цієї проблеми можуть стати українські народні пісні про кохання, які містять чи не найкращі зразки, вказівки на національні стереотипи поведінки молоді. Водночас у них відбилися погляди щодо порушення морально-етичних норм, однією з яких вважали втрату вінка, тобто дошлюбні статеві стосунки. Українці прискіпливо ставилися до сфери інтимного, особливо якщо це стосувалося неодруженої молоді, адже з цим пов'язана низка вірувань та уявлень щодо продовження роду.

Мотиви втрати вінка $є$ популярними не лише в українських народних піснях, їх можна відшукати й у фольклорі інших народів. Детальний аналіз пісень відповідної тематики здійснив свого часу В.Гнатюк у праці «Пісня про покритку, що втопила дитину», у якій дослідив понад 22 варіанти пісень, подав вказівки на друковані паралелі, проаналізував тексти 3 такими мотивами в інших народів. Учений наголосив, що метою розвідки $є$ не літературна сторона, а розбір «культурних пережитків» $[1,251]$, проте подав багатий джерельний матеріал. Особливе зацікавлення до пісень із такими мотивами склало основу праці К.Квітки «Українські пісні про дітозгубницю», у якій автор, крім того, що подав ряд варіантів, проаналізував їхню віршову та музично-ритмічну форму [6]. Сучасні дослідники народних пісень про кохання, хоча й звертаються до теми еротичного в народних піснях, усе ж не увиразнюють саме цього аспекту проблеми. Полісемантичні топоси еросу в ліричних піснях проаналізувала Л.Копаниця, порівнявши їx iз відповідними весільними, простежила символіку еротичного у досліджуваному жанрі та фольклорі загалом [7, 228-242].

Метою нашого дослідження $\epsilon$ аналіз любовної лірики з мотивами про втрату «вінка» та висвітлення основних морально-етичних норм співжиття молоді, ставлення до неї суспільства. Актуальність проблеми полягає у з'ясуванні можливостей цього популярного жанру 
накопичувати і передавати цілу систему уявлень про морально-етичне виховання української молоді XVIII - початку XIX століття.

Результати дослідження. Одним із найпоширеніших символічних образів, яким в українських народних піснях про кохання позначають втрату дівочої цнотливості, $є$ втрата вінка. Вираз «втрата вінка» має кілька народнопоетичних синонімів - зрада, підмова:

Гой ще не дійшли вишневого саду,

А й зробили вже над дівчиною зраду $[8,86]$.

Ой, дівчино, дайся на підмову,

То виведу з гаю на дорогу $[11,129]$.

Саме дівчата повинні були дотримуватися статевої чистоти, адже їхня невинність могла бути доведена під час першої шлюбною ночі. Тому в народній пісні часто звучить застереження дівчатам:

Не стій, дівко, із парубком, не май йому віри:

У парубка така віра, як на воді піна,

Ой в дівчини така ласка, як на воді ряска $[14,104]$.

Порівняння вірності парубка 3 піною на воді, яка швидко зникає, підкреслює швидкоплинність його почуттів, недотримання обіцянок тощо. Згадка про ряску, що стелиться на поверхні води, також не випадкова. Дівчина все ж довіряє хлопцеві: «А я тую ряску заберу в запаску, А я тому козаченьку подійду под ласку $[14,104]$. Під виразом «подійду под ласку» мається на увазі сподобатися парубкові й одружитися з ним, чим буде покрита неслава дівчини. Рослинний символ - ряска, яку дівчина доглядає, означає збереження дівоцтва, а зібрати ряску в запаску - слугує у тексті позначенням наявності статевих стосунків.

Як правило, у піснях про кохання, як і загалом в українському фольклорі, стосунки між парубком і дівчиною позначалися певними інакомовленнями: «наробити дівчині лиха», «борозну притиснути», «орати плужечком» і т. д. Образ чоловіка-орача об'єднує мотиви цього жанру із відповідними весільними, адже «у весільній обрядовості з чоловічого боку статеві зносини передаються символікою: чоловік править конем, оре плугом землю» [7, 237]. 3 цього приводу дослідниця народних пісень Л.Копаниця зазначила: «Якщо прокреація, відновлення життя співвідноситься 3 космогонічним процесом, тим самим походження й смисл фольклорної еротики пов'язані з певними міфопоетичними ідеями: поєднання жіночої відтворювальної сили й чоловічого начала як джерело життя, усвідомлення землі як жіночого організму, сприйняття мотиву процесу статевих зносин із землею як шлюбних стосунків між небом і землею, що дає початок життю, коїтус долає владу і полон смерті» [7, 240]. Відбір аграрних символів і маркування ними статевих стосунків свідчить про ментальне сприйняття українців свого світу.

У зв'язку з тим, що українці - нація хліборобів, відповідні мотиви пронизують весь фольклор, тому і народні пісні про кохання не стали винятком. Згадки про господарські процеси (сіяння, виполювання, жнива, в'язання снопів, молотьба тощо) з'являються у піснях не механічно, а є результатом метафоричного переосмислення дійсності. Мотиви народних пісень, які описують зелене збіжжя і роботи, пов'язані з цим, розкривають перебіг становлення (формування) молодої пари, а ті, у яких йдеться про достигання злаків, жнива, в'язання снопів вказують на готовність (переважно дівчат) до шлюбу, на підготовку до весілля. Немалу роль при цьому відіграють опосередковані описи самих рослин (зелене жито, колос похилився), які у піснях, на перший погляд, є тлом зображення ситуацій, але мають глибоке символічне навантаження.

Особливої уваги заслуговує образ засміченого збіжжя, що з'являється часто у піснях, де йдеться про порушення моральних норм особистого життя, - пісні про зведення дівчини, незаплановану вагітність чи народження позашлюбної дитини:

За горою крам'яною

Росте жито $з$ осокою,

А пшениця з лободою [3, 269].

Інший варіант пісні продовжує картину таким описом:

Там Мар'яна жито жала,

В правій руці серп держала,

А лівою жменю брала $[13,283]$. 
Уже в перших рядках пісні змальовано порушення упорядкованого плину життя. Традиційний мотив зображення жнив указує, що дівчина, яка жне жито, є готовою до створення сім'я. Пісня розкриває образи хлопця і зведеної дівчини, яка дорікає парубкові за зламаний вінець. В іншому варіанті пісні зображується нещасливе кохання: дівчина народила дитину, а милий покинув іiі. Негатив образу парубка посилено згадкою про те, що він солдат, перебуває далеко від дівчини та ії дитини («бо вже отця не видати», «а вже отець на Вкраїні»). Отже, зображене порушення звичаєвої норми у пісні передано описом хаосу, нечистоти, безладу як у полі, так і в особистому житті. Жито з лободою, яке жне дівчина, виступає метафорою занедбаного дівочого життя:

Вже Мар'яна не дівочка.

Вже ж Мар'яні не гуляти, -

Треба дитя колисати $[13,283]$.

Народна лірика кохання увібрала в себе усі норми звичаєвого права, метафорично переосмисливши і порівнявши їх із упорядкованим, нехаотичним плином речей. Безлад у господарстві порівнюється з непорядком у стосунках, через що в основному і відбуваються порушення морально-етичних норм.

Дівчата, як простежується з народних пісень, дуже шкодують, розуміючи, що порушили традиційні норми моралі, які дозволяють статеві стосунки тільки одруженим:

Ночувала другу в калиновім лугу,

3 тобою не звінчана буду.

Ночувала третю в хрещатім барвінку,

Я з тобою не звінчана в вінку $[14,98]$.

Шкодуючи про вчинене, дівчата намагаються відшукати свій вінок, повернути його, але це, зрозуміло, неможливо. Ця незворотність підсилюється тим, що дівчина не знаходить помічників у пошуку втраченого вінка, тобто вважає себе винною за скоєне:

- Гулане, гулане,// Де-сьте коні пасли?

Згубила-м віночок,// Ци-сьте ми ни найшли?

- Ми коні ни пасли,// Лишинь напавали,

Два вінки павляні// По морю плавали.

- Гулане, гулане,// Сідайте на коні,

Їмайте віночки,// Бо то вінки мої.

На Дунай поплыли,// Мы їх не їмили.

Молода дівчино,// Ни твої то были [16, 285].

У такій метафоричній формі передано безповоротність утрати вінка. Покарання за це для дівчини - шлюб без віночка (якщо взагалі він міг відбутися), адже хлопці мали право відмовитися від шлюбу із зведеною дівчиною, якщо їхня провина в цьому не була доведена. Страх перед таким покаранням був надто великий, тому часто дівчата почувалися у повній безвиході: «Ой гіля, сірі гуси, Ой гіля на ріку; Зав’язала головоньку - Не розв'яжу до віку!» [14, 354].

Особливими у народній творчості можна вважати пісні про кохання, в яких наявний мотив «дівчина мандрує із зводителем». Дівчина покидає межі «свого світу», мандрує із «зводителем», переважно чужинцем, чим порушує ряд моральних норм і торкається міфологічного пласта світоглядних уявлень. «У ліричній пісні про кохання, як і в обряді та обрядовій поезії, зазначаємо чіткий і твердий поділ простору на «свій» і «чужий» світ. «Чужий» світ завжди наділений атрибутами міфологічного «того» світу, а «свій» - сакралізується. Цей «чужий» інший світ завжди віддалений від світу людини, для його досягнення необхідні значні зусилля, тому головною характеристикою і просторовою категорією цієї моделі «чужого» світу у фольклорі є далека, небезпечна дорога. А умовою проникнення через кордони між цим «чужим» світом і «своїм», їх непрозорість знаходиться у стійкій залежності від часу» [7, 204]. Саме у «чужому» просторі дівчина-героїня народної пісні про кохання часто втрачає вінок:

Заснула дівчина, як ожиця в лісі,

Козак коло ниї лежит та й смієся [16, 284].

Посилює відчуття «чужого» простору також образ чужинця, що часто присутній у піснях із таким мотивом. У своій розвідці К.Квітка, хоча й утримувався від «літературних зближень, розшукувань та здогадів», розмістив значну кількість текстів із провідним мотивом «дівчина помандрувала із зводителем», де зводителі - це козаки (з Україноньки або донські), 
чужоземці, мандрівні шевці, ляшки, Марко, матроси на кораблі, Стефан воєвода [5]. Мотиви зазначених текстів головно належать до баладних, що доповнює розуміння порушення морально-етичної норми.

Звідники пропонують легковажним дівчатам безтурботне й багате життя та інші принади:

Мандруй, мандруй, дівча, з нами,

Ліпше буде, як у мами:

В нас криниці рубленії,

В нас ріки медянії,

В нас верби грушки родять,

В нас дівки в злоті ходять $[14,335]$.

Іноді звабники пропонують набагато скромніші подарунки - напої. «Пити (мед, вино, горілку) в народній пісні про кохання набуває і додаткової семантики - це загубити дівоцтво, мати лиху долю» [7, 202]:

Єден каже: «Вином»,

Другий: «Горівочков».

Ото то ж, ото то

Зрада над дівочков.

Ой за гальбу пива,

А за другу вина

Ни будеш, дівчино,

Віночок носила $[16,285]$.

Однак, здебільшого дівчата не погоджувалися на підмову і мудро обороняли свою честь: «Горілки не п’ю, медом, вином не вп’юся, Серце-козаче, я тебе не боюся» $[14,340]$. Інколи підкупити дівчат намагаються також прикрасами, наприклад, стрічками: «Дівчинонько, куплю тобі стрічку, Переночуй зо мною хоч нічку» $[14,161]$, іноді взуття: «Дамо тобі чобіточки сап'яні. Дамо тобі черевички з застьожками» $[14,339]$. Дівчата погоджуються 3 корисливих мотивів. Донька у розмові з матір'ю саме так мотивує свій вчинок: «На жупання, моя мати, на жупання, Я думала, що я буду за ним паня; Я ж думала, що я буду за ним попадічка - Не вилізе біла ніжка 3 черевичка» $[14,340]$.

У народній пісні про кохання постійно відчувається цілеспрямованість оберегти дівчину від непоправних вчинків. До цього задіяні сили природи, все довкілля. Так, метафорично «куванням-повідомленням» зозулі передається застереження дівчині не слухати всіх обіцянок парубка, щоб не втратити свого вінка:

Прилетіла зозуленька:

- Не слухай, дівчинонько,

Бо я весь світ пролітала,

Золотих горів не видала.

3 вербів грушок не їдала,

Дівок в злоті не видала.

Дівка зозулі не слухала,

С козаками поїхала $[14,336]$.

Як відомо, в українському фольклорі саме ця пташка володіє певними сакральними знаннями. Дослідниця образу зозулі в українській усній словесності Н.Пастух на підставі аналізу різножанрових творів вважає, що «віра в об'ємність і повноту знань зозулі настільки велика, що на їі основі постає висновок: чого зозуля не бачила, того просто не існує» $[12,109]$.

Незалежно від того, чому відбувається втрата «вінка», в усіх випадках українська дівчина усвідомлювала, яке незворотне порушення вчинила. Страх перед втратою «вінка» можна пояснити тим, що дівчата були свідками покарань зведених дівчат:

Не так ся бою коня вороного,

Як я ся бою козака молодого.

Бо кінь наздопче, то знайдуться ліки,

А козак зрадить, - неслава навіки $[10,38]$.

Особливо складними для дівчини були наслідки втрати вінка. Про це у народній пісні про кохання зазначено так: «Дівкою гуляй - людська обмовочка, А замуж піти - бідная головочка» $[14,340]$. Дівчина розуміє, що після порушення такої стратегічно важливої 
соціальної норми - втрати «вінка» - життя у шлюбі буде нещасливим, адже вона вийшла заміж «нечесною». Отже, людський поговір є одним із вагомих факторів стримування дошлюбних статевих стосунків.

Сором за скоєний вчинок часто примушував дівчат до зізнань батькам чи громаді. Зізнання своєму родові про втрату дівочості були дуже емоційними, адже дівчина не виправдала сподівань батьків, та й рід дівчини 3 того моменту не вважався «добрим», «чесним», бо не зміг виховними чи іншими засобами втримати дівчину від такої провини. У народних піснях про кохання ці мотиви $є$ надзвичайно драматичними: дівчата повністю усвідомлюють свою провину, нарікаючи на власний розум, і покладають провину за цей моральний злочин тільки на себе:

- Ой ви, хлопці-чужоземці,

Накажіть же моїй неньці -

Нехай торгом не торгує,

Нехай вінків не купує,

Потеряла свій віночок

Через дурний розумочок,

Потеряла щастя-долю

Через свою дурну волю $[9,138]$.

Емоційний фон пісні підсилюють епітети дурний, дурна, вжиті до слів розум, воля, що підкреслюють усвідомлення власної відповідальності за скоєне. Подібними є мотиви, у яких дівчина, що «ізгубила свій віночок под яворком зелененьким з козаченьком молоденьким» $[15$, 461], повідомляє про цей факт батькам, роду листом. Це є натяком на мандрівку, куди вона відправилася, піддавшись на вмовляння хлопця, з одного боку, і намагання уникнути, знайти психологічних вихід із цієї вкрай складної ситуації, з другого. Зраджена дівчина просить не купувати їй шлюбного вінка, адже не матиме права його одягнути:

Да напишем по письмечку,

Да пошлемо до отця, неньки,

І до родной родини,

I до вірной дружини,

Нехай вони мною не турбують,

Нехай вінка не купляють,

Нехай мені серпанок готують [15, 461].

Доля дівчат, які втрачали цноту до весілля, могла складатися двома шляхами: або хлопець покриває неславу й одружується з дівчиною, яку звів; або ж на дівчину очікувала доля покритки. Існували особливі звичаї покривання голови дівчині, яка втратила цноту, без шлюбу. «Покритка» («скритка», «накритка») - так у народі називали жінку, яка втратила дівочість поза шлюбом і якій, як заміжній жінці, покривали голову хусткою» $[4,190]$. Покритка, звичайно, виключалась із дівочої громади, не мала права ходити з непокритою головою, в церкві стояти поруч із дівчатами. Вона продовжувала жити в домі своїх батьків, але над нею могли посміятися, при нагоді кинути докір, а іноді й поспівчувати $[2,179]$. Почуття провини було настільки сильним, що навіть перед покриванням дівчина не могла собі дозволити стати в один ряд 3 дівчатами чи одягнути вінок: «Я до дівок не потрібна, Я до вінка не способна» $[14,335]$, акцентується в народній пісні про кохання.

Покритки не уникали покарання. Здебільшого це були традиції, пов'язані із косою, волоссям: вони мали покривати голову, на відміну від «чесних» дівчат, які ходили із непокритою головою, прикрашеною вінком або стрічками. В «обряді «покривання» втілено виховний та застережний ефект, спрямований на молодь, - на саму покритку, оскільки осуд громади випереджав народження дитини, i вона перебувала під пильною увагою своїх односельців, а це унеможливлювало здійснення більших злочинів (приховування факту народження дитини, вбивство дитини)» [4, 190]. Покривання молодої під час весілля і покривання зведеної дівчини - функціонально однакові ритуали, проте покритка, як зауважив В.Гнатюк «дійшла до нього не тим самим шляхом, що молода, - як пісня говорить: «Ти, дівчино, ні дівка, ні жінка, Бо с не мала на голові вінка» $[1,308]$. Тобто вінок, як і його відсутність в обряді покривання, стає виразником особливої ситуації - маркує «неформальну», незаконну втрату цнотливості, що було одним із найважчих порушень моральних норм. 
Щоправда, у піснях досліджуваного жанру назва «покритка» фігурує дуже рідко: «Нi дівчина, ні вдова, Покриточка молода» $[13,290]$. Здебільшого це слово замінено описовою конструкцією, що повністю окреслює статус такої дівчини:

Ой тепер я ні дівчина, ні вдова,

Гей тепер я вже на віки пропала $[14,339]$.

А тепер же ти ні жінка, ні дівка,

А тепер же ти людська поговірка [14, 337].

Саме так у народних піснях про кохання означується образ покритки («ні дівчина, ні вдова»; «ні жінка, ні дівка»; «людська поговірка»). Нерідко замість цієї номінації акцент зроблено все ж на слові «поговір», від чого й маємо «людська поговірка». Крім того, в піснях про кохання подано поетичне розуміння маргінальності образу зведеної дівчини, адже ії не зараховують до жодної із соціальних верств.

Висновки. Отже, в народних піснях про кохання йдеться про одне 3 найбільших порушень щодо етики і моралі українського суспільства - втрати «вінка». Зведена дівчина опиняється у вкрай складному соціальному становищі, адже на неї очікують тільки громадський осуд, неможливість вдало (чи й взагалі) вийти заміж, реалізувати інші соціальні ролі (жінки-покритки не брали участі у весільному обряді, не могли стати повитухами, їх цуралися односельчани). Водночас у народних піснях про кохання із відповідним мотивом демонструється не лише засудження, а й співчуття до дівчини, закцентовано на показі почуттів зведениці, іiі щирому каятті у скоєному вчинку, на розумінні незворотності звичного плину подій для самої дівчини та ії роду. Тексти таких пісень $є$ певними моделями антиповедінки, зразками покарання зведених дівчат, на прикладах цих героїнь абсолютно чітко простежується соціальний стандарт виховання української молоді.

\section{ЛІТЕРАТУРА}

1. Гнатюк В. Пісня про покритку, що втопила дитину // Матеріали до української етнології. — Львів, 1919. - T. 19-20. - C. 249-389.

2. Горинь Г. Громадський побут сільського населення Українських Карпат (XIX - 30-ті pp. XX ст.) К., 1993. -200 c. $-165 \mathrm{c}$.

3. Гринченко Б.Д. Этнографические материалы, собранные в Черниговской и соседних с нею губерніях. Том III. песни. - Чернигов, 1899. - 765 с.

4. Івановська О.П. Звичаєве право в Україні. Етнотворчий аспект. Навчальний посібник. - К, 2002. $264 \mathrm{c}$.

5. Квітка К. Українські пісні про дівчину, що помандрувала з зводителем // Етнографічний вісник. К., 1926. - Кн. 2. - С. 78-107.

6. Квітка К. Українські пісні про дітозгубницю. - Київ, 1927 . - 62 с., (додатки, 8 с.).

7. Копаниця Л.М. Поетичний текст в усній і книжній традиції: Питання поетики та художньої семантики: навчальний посібник. - К., 2010. - 397 с.

8. Народні пісні Буковини в записах Юрія Федьковича. - К., 1968. - 222с.

9. Народні пісні в записах Івана Манжури. - К., 1974. - 351 с.

10. Народні пісні в записах Маркіяна Шашкевича. - К., 1973. - 111 с.

11. Народні пісні в записах Степана Руданського. - К., 1972. - 291 с.

12. Пастух Н. Символіка тварин в українському фольклорі: зозуля. - Львів, 2013. - 224 с.

13. Пісні кохання / Упоряд., вст. ст. та прим. Дея О.І. - К., 1986. -367 с.

14. Труды этнографическо-статистической экспедиции в западнорусский край. Материалы и исследования, собрание д.чл. П.П.Чубинским. Том пятый. Песни любовные, семейные, битовые и шуточные. - СПб, 1984.

15. Українські народні пісні в записах Зоріана Доленги-Ходаковського / Упорядкування, текстологічна інтерпретація і коментарі О. І. Дея.- Київ, 1974.—782 с.

16. Фольклорні матеріали з отчого краю / Зібрали Василь Сокіл та Ганна Сокіл. У ноти завела Лариса Лукашенко. - Львів, 1998. - 614c. 